\title{
Spanish Moss, Ball Moss, and Lichens - Harmless Epiphytes ${ }^{1}$
}

\author{
Joe Sewards and Sydney Park Brown²
}

Epiphytes are "air" plants that survive on moisture and nutrients in the atmosphere. Several epiphytic plants, like Spanish moss, ball moss, and lichen, are common to the Florida landscape and southeast United States. People unfamiliar with epiphytes sometimes worry that they may cause injuries to the plants they perch in. Epiphytes do attach themselves to plants, but they do not harm the plants, unlike mistletoe, a plant parasite. Without soil as a source of nutrients, epiphytic plants have evolved the capacity to obtain minerals dissolved in water that flows across leaves and down branches.

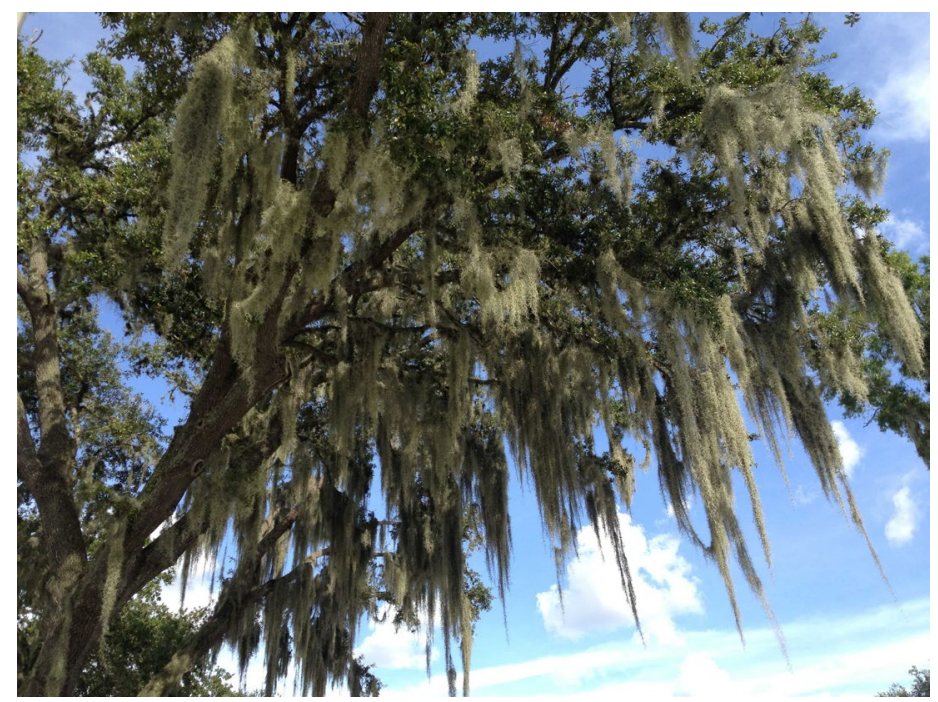

Figure 1. Often misunderstood, Spanish moss is a natural feature of southern landscapes.

Credits: Sydney Park Brown
While epiphytes may grow on wires, fences and other non-living structures, they are particularly well-adapted to well-lit, moist habitats commonly found near rivers, ponds and lakes. Epiphytes will also grow in areas where the humidity is fairly high.

\section{Spanish Moss and Ball Moss}

Some early Floridians earned their livelihood collecting Spanish moss, which was used to stuff car cushions and upholstery. At one time, there were 35 moss-processing plants in Florida. The last operating factory burned in 1958 and never reopened. Today, Spanish moss is collected and used by the craft and floral trade.

Despite their common names, Spanish moss (Tillandsia usneoides) and ball moss (Tillandsia recurvata) are not mosses, but members of the Bromeliad family. Spanish moss (Figure 1) is easily recognizable by its pendant strands. Ball moss (Figure 2) is a small, tufted, gray-green plant. Both prefer high light and will therefore thrive on weak or dead trees that have lost their leaves. However, their presence on a dead or dying tree does not implicate them as the cause of the plant's deterioration. Rather, decline of the host tree was likely because of soil compaction, root damage, altered drainage, or other problems that can compromise plant health. Spanish moss may speed the decline of already declining trees. This is because branches heavily laden with Spanish moss may shade lower

1. This document is ENH1224, one of a series of the Environmental Horticulture Department, UF/IFAS Extension. Original publication date September 2013. Visit the EDIS website at http://edis.ifas.ufl.edu.

2. Joe Sewards, urban horticulture agent, Volusia County; Sydney Park Brown, associate professor and Extension specialist - Consumer Horticulture, Department of Environmental Horticulture; UF/IFAS Extension, Gainesville, FL 32611. 
leaves, intercepting light needed for photosynthesis, or it may conceal structural defects that a land manager might otherwise have spotted and repaired. These concerns are significant only for trees that are already in decline; in most instances Spanish moss is completely harmless and only adds aesthetic appeal. Limb breakage is often attributed to the weight of the moss, but in fact moss contributes an insignificant amount of weight and is almost never a factor in broken branches. In reality, the branch was likely weak or damaged and would have failed on its own. Bottom line: Plant damage resulting from Spanish or ball moss is uncommon, and removal is expensive. Consult with an International Society of Arboriculture (ISA) Certified Arborist before attempting to remove moss. These professionals can assess the health and structure of your tree(s) and determine if moss removal is justified.

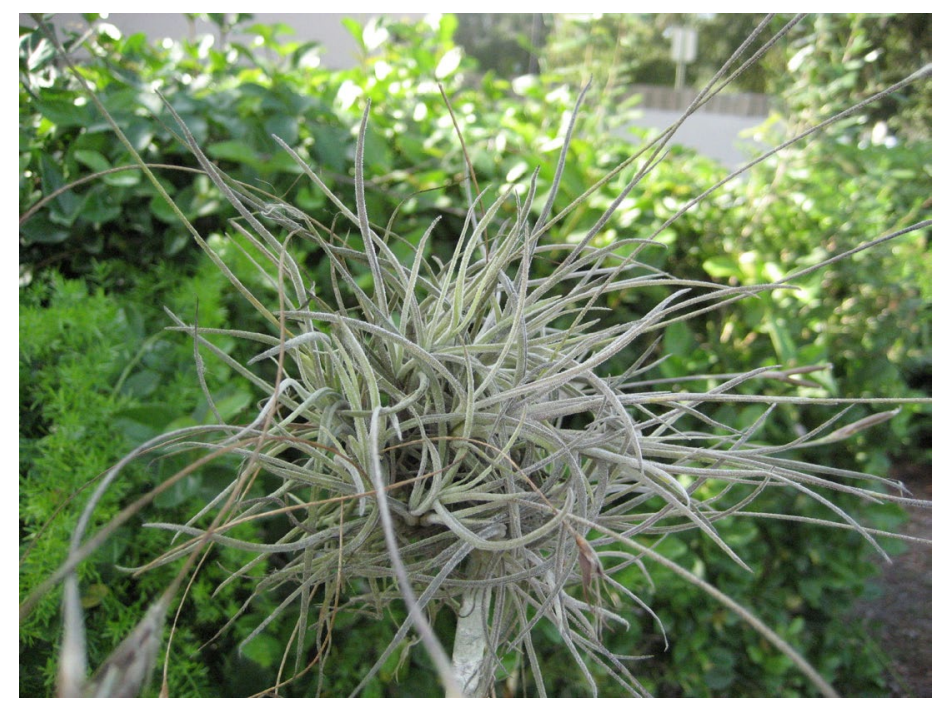

Figure 2. Ball moss may grow on a dying tree, but it is not the cause of a tree's decline.

Credits: Sydney Park Brown

Another misconception about Spanish moss is that it harbors a biting insect commonly called a chigger or redbug. The natural habitat of these creatures is mostly low, damp areas with heavy natural vegetation. Fallen mossand any plant material on or near the ground-may contain chiggers, but moss in trees hanging above the ground rarely harbors them.

Many animals use Spanish moss for protection, taking cover in its thick masses. A number of insects and other invertebrates hide and breed in Spanish moss. Two species of bats use garlands of Spanish moss as day-time resting sites. Zebra longwing butterflies roost in it at night (Figure 3). Many species of birds use strands of moss to build their nests. Spanish moss is a significant component of the nests of Parula warblers and the Baltimore orioles, which weave the moss into hanging sacks to hold eggs and young.

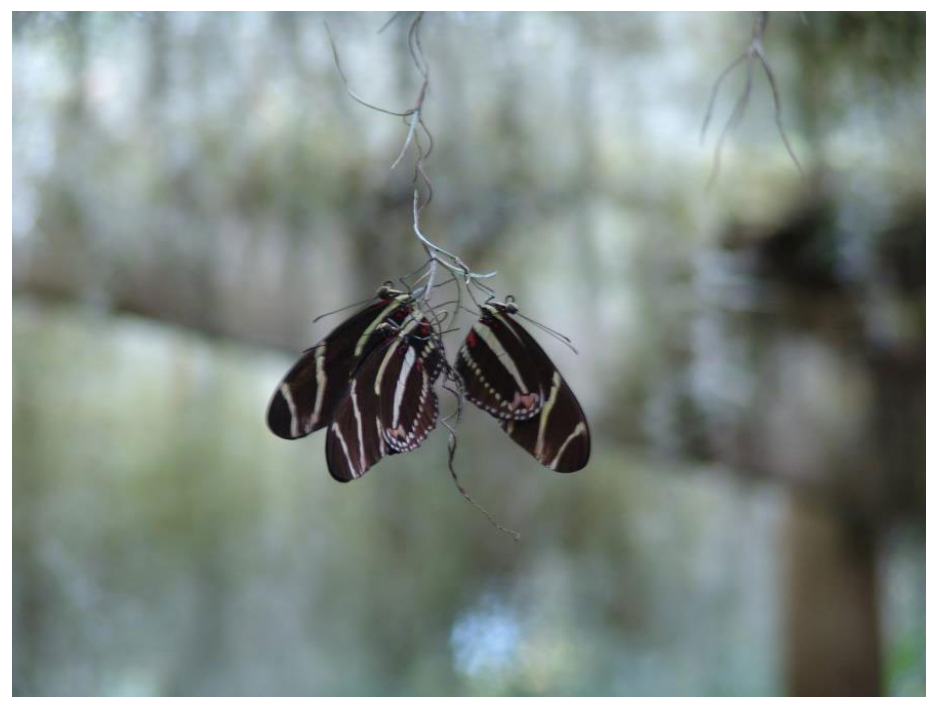

Figure 3. Zebra Longwing butterflies communally roost in Spanish moss.

Credits: Sydney Park Brown

In cases where moss appears unsightly or prolific, hand removal is possible and can be performed successfully on small trees by standing on a ladder or using a pole. For larger trees, a "cherry-picker" is usually necessary. Chemical control is possible, although not generally necessary. The following materials are labeled for control of Spanish moss and/or ball moss: TC Tribasic Copper Sulphate, Blue Shield, Basic Copper 53, Micro Flo Basic Copper 53, Micro Flo Copper 3 FL. It should be noted that there is evidence that copper-based herbicides and fungicides may cause damage to tender growth on oak trees. As with all chemicals, read and follow label directions carefully when using these materials. Also, keep in mind that, if you choose to apply herbicides to the moss, the dead moss will be more unsightly than it was when it was alive, and it will still need to be removed. Also, take care when spraying large trees. You may inadvertently spray your neighbor's property and damage plants that are sensitive to such chemicals.

\section{Lichens}

As with Spanish moss and ball moss, lichens are often blamed for the decline and death of shrubs and trees. And, as with Spanish moss and ball moss, although lichens are frequently seen growing on the bark of plants, they do not cause harm.

Lichens are interesting organisms consisting of a fungus and an alga growing together in a mutually beneficial relationship. The fungus obtains water and minerals from the air and the material it is growing upon and provides 
structure and protection for the alga. The alga provides carbohydrates and vitamins the fungus needs to grow. Nitrogen is obtained from bird excrement, organic debris, or plant leachate. The entire fungus/alga structure, called a thallus, is so different structurally from either of its partners that microscopic examination is necessary to distinguish the fungus from the alga. Lichens may be flat, leafy, or hair-like (Figures 4 and 5). All three forms occur on tree bark as well as on rocks, soil, fence posts, etc. Colors may range from white to gray, red, green, yellow, or black. The presence of some lichens is normal on many Florida trees and shrubs, but heavy lichen growth often indicates poor plant growth and decline from environmental stresses, damage, or poor management. Defoliated branches on declining plants provide increased access to sunlight which in turn causes lichens to thrive.
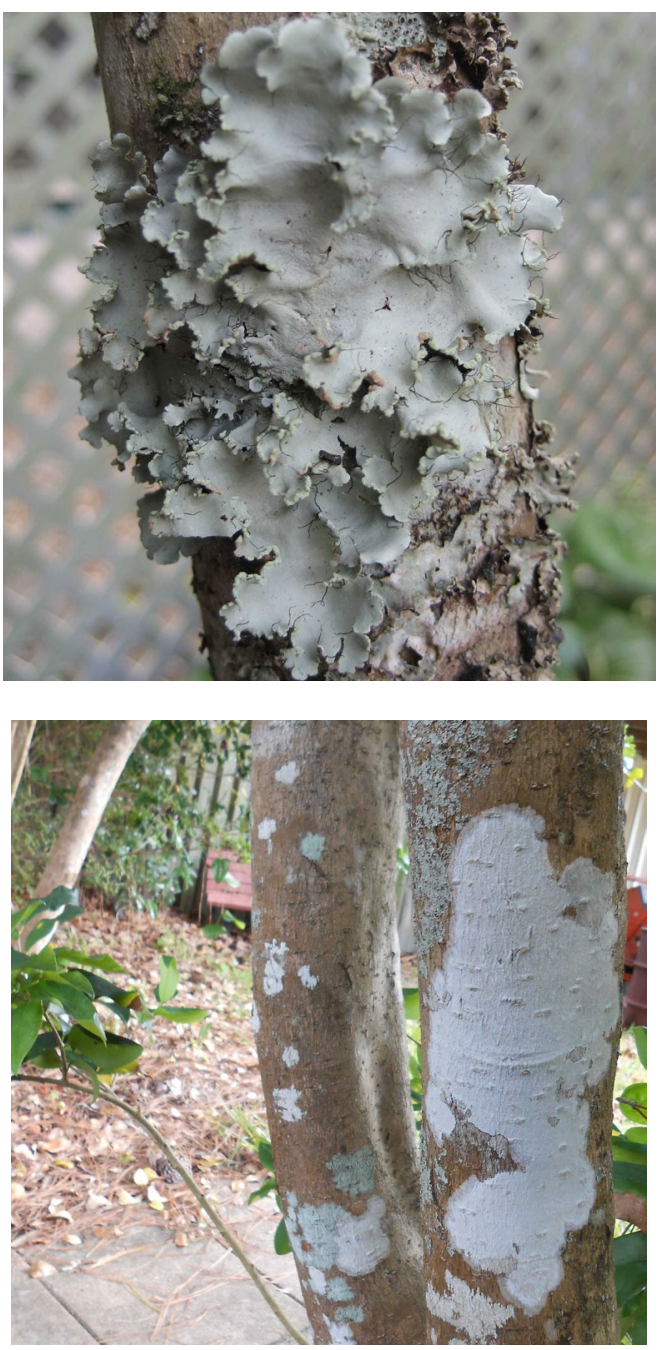

Figures 4 and 5. Lichens come in many forms. Although lichens are commonly blamed for the decline and death of shrubs and trees, they do not cause harm.

Credits: Sydney Park Brown and Joseph Sewards

\section{Conclusion}

Spanish moss, ball moss, lichens and other epiphytes growing on living and dead trees are part of the image of the Florida landscape. Given the roles these plants play in the natural environment and the native beauty they impart, the best strategy is to leave these unique and harmless plants unmolested.

\section{References}

Arny, Nancy P. 1996. Spanish moss and Ball Moss CIR FOR-52. School of Forest Resources and Conservation Department -IFAS, University of Florida, Gainesville.

B. Larson, et al. 2005 (reviewed 2013). "Florida's Native Bromeliads." (CIR 1466). Department of Wildlife Ecology and Conservation. UF/IFAS Extension, Gainesville, FL.

Reeves, Connie. 1999. Lichens on Trees, University of Minnesota Extension; Yard and Garden Brief.

University of Florida/IFAS, Solutions for Your Life, Spanish moss, http://solutionsforyourlife.ufl.edu/hot_topics/ environment/spanish_moss.html

United States Department of Agriculture/Natural Resources Conservation Service, Plants Database, http://plants.usda. gov

Hagan, Austin. 2004. "Lichens on Woody Shrubs and Trees ANR-857. Auburn University Extension System.

Hand, Sam. 2013. "Spanish moss - A Southern Treasure." Tallahassee Democrat.

Jensen, A. S. 1982. "Spanish moss." School of EPForest Resources and Conservation Fact Sheet - FRC-245. IFAS, University of Florida, Gainesville. 